\title{
АГРОНОМІЯ
}

\section{PRODUCTION OF TEXTILE CROPS IN CONDITIONS OF RADIOACTIVE CONTAMINATION}

\author{
V. Kovalev ${ }^{1}$, I. Derebon' ${ }^{1}$, T. Klymenko ${ }^{1}$, S. Fedorchuk ${ }^{1}$, \\ O. Trembitska ${ }^{1}$, M. Lisovyy ${ }^{2}$ \\ ${ }^{1}$ Житомирський національний агроекологічний університет \\ (м. Житомир, Україна) \\ e-mail: K82_super@ukr.net \\ e-mail: iderebon@gmail.com; ORCID: 0000-0002-6139-6286 \\ e-mail: tatiana-radko@ukr.net; ORCID:0000-0002-2071-6802 \\ e-mail:svetavanasveta@gmail.com
}

e-mail: ksyusha.trembitskaya@gmail.com; ORCID: 0000-0003-1152-0215

${ }^{2}$ Національний університет біоресурсів і природокористування України

(м. Київ, Україна)

e-mail: lisova106@ukr.net; ORCID:0000-0002-7289-1098

\begin{abstract}
Після аварії на ЧАЕС значна частина земель Поліської зони виявилась забруднена радіонуклідами, які відповідно до чинних нормативних актів виведені з землекористування, тому нами проаналізовано сучасний стан галузей льонарства та коноплярства в Україні. Чорнобильська аварія призвела до радіоактивного забруднення великих плош, сільськогосподарських угідь, тому дедалі більще привертають увагу роботи вчених, спрямовані на зниження радіоактивного забруднення. Обгрунтована можливість вирощування луб'яних культур в умовах радіоактивного забруднення, розглянуті елементи технології вирощування та первинної й глибокої переробки льону та конопель, що дають можливіть істотно зменшити надходження радіоактивного иезію ${ }^{137}$ Сs в продукцію рослинництва та вміст його в різних видах продуктів переробки иих культур. Запропоновані конкретні контрзаходи для досягнення цієї мети, а саме: при вирощуванні льону та конопель вносити фосфорно-калійні добрива, які знижують надходження радіонуклідів у продукцію, що вирошується в умовах різних рівнів радіоактивного забруднення, посів льону проводити сумісно з нещільнокущовими злаковими травами, застосовуючи для цього норму висіву 15-20 кг насіння трав. При вилежуванні соломи льону до трести проводити обертання стрічок, що дає змогу знизити накопичення радіонуклідів за рахунок зменшення маси пилоподібних домішок і уникнення прямого контакту продукції первинної переробки з грунтом. Тресту перед переробкою на м'яльно-тіпальному агрегаті рекомендовано промивати у водному потоці на віджимно-промивній машині.
\end{abstract}

Ключові слова: льон олійний, льон-довгунець, коноплі, рослинна олія, радіоактивний иезій $\left({ }^{137} \mathrm{Cs}\right)$, фосфорні добрива, шрот, макуха.

\section{INTRODUCTION}

In accordance with the legislation of Ukraine, lands on mineral soils contaminated with radionuclides over $15 \mathrm{Ci} / \mathrm{sq}$. $\mathrm{km}$ and lands on organic soils with a level of pollution over $5 \mathrm{Ci} / \mathrm{sq}$. $\mathrm{km}$ are withdrawn from land use. Other lands are used for agricultural

(C) V. Kovalev, I. Derebon, T. Klymenko, S. Fedorchuk, O. Trembitska, M. Lisovyy, 2020 activities. The content of radionuclides in the products produced on them should not exceed the current standards. The man-made Chernobyl accident has led to radioactive contamination of large areas of agricultural land, so the work of scientists aimed at reducing radioactive contamination by biotechnological methods is attracting more and more attention [1]. 
At the same time, studies show that radionuclide-contaminated soils can be used to grow industrial crops that accumulate minimal radionuclides and are not grown for food. Such crops are linseed flax, fiber flax, hemp and other textile crops.

In Ukraine, fiber flax in the 90 s of the twentieth century was grown on the area of 160 thousand hectares. Due to the decrease in the area under fiber flax in recent years, linseed flax has been cultivated in Polissya of Ukraine, including Zhytomyr region. Linseed flax is a crop that has become an alternative to sunflower and rapeseed. According to the State Statistics Service of Ukraine, in 2017 the sown area under fiber flax was 1.5 thousand hectares in Zhytomyr, Chernihiv, Lviv, Rivne and other regions. In the same year, the sown area under crown flax was 45.8 thousand hectares mainly in Odessa, Mykolaiv, Kherson, Kharkiv, Zaporizhzhia and Zhytomyr regions [2].

\section{ANALYSIS OF RECENT RESEARCH AND PUBLICATIONS}

The tendency to increase the area under linseed flax, in addition to economic interest, is largely explained by global climate change. Climatic and soil conditions of Central Polissya with the introduction of the required amount of nutrients correspond to the biological characteristics of linseed flax of mezheumka type. Linseed flax in Zhytomyr region has normal growth and development, provides an average seed yield of 1.5-1.6 t/ha, straw of $2.0-2.3 \mathrm{t} / \mathrm{ha}$ and fiber of $1.6-$ $2.2 \mathrm{c} / \mathrm{ha}[2]$.

Linseed flax, in contrast to fiber flax, is a raw material for the production of food and technical oil: linseed flax seeds contain 42$49 \%$ of oil, which is $7-12 \%$ higher than that of fiber flax. Flaxseed oil is a leader among vegetable fats in its biological value. It is the richest source of polyunsaturated fatty acids, the content of which in flaxseed oil is several times higher than in fish oil. The content of essential linolenic fatty acid in flaxseed oil reaches $50-70 \%$, and vitamin $\mathrm{C}-50 \mathrm{mg} /$ $100 \mathrm{~g}$ [3; 4]. Hemp should be attributed to crops similar in chemical composition of oil.
This rare culture of Polissya allows to improve the sanitary condition of the soil. At the 4th Conference in Rouen (1996), Polish experts in the report Reclamation of lands contaminated with radionuclides» stated important facts of reducing the content of heavy metal salts in soils sown with hemp.

Thus, hemp and its processed products have significant environmental value. This is due to the fact that marketable products in the cultivation of hemp is used mainly for technical purposes, i.e. it does not give additional radiological load on humans, in the cultivation of hemp to obtain fiber, chaff and seeds [5].

Hemp fiber is used to make ropes for the navy and river fleets, cores for steel ropes, twine, household and technical rope, fire hoses, tarpaulin, and various technical fabrics. Hemp fiber is used in the oil industry, construction, for the manufacture of securities. The seeds are used to make oil, oil cake meal, and medicines. Oilcake contains up to $28 \%$ of protein, $9-11 \%$ of fat. It is used as a valuable feed for farm animals. Waste of primary processing of hemp (chaff) is a valuable raw material in the manufacture of hemp particle boards for the furniture industry and construction [5].

\section{MATERIALS AND RESEARCH METHODS}

The aim of the research is to determine the possibilities of growing flax and hemp in conditions of high levels of radioactive contamination of soils. For this, we used the materials of our research on the co-sowing of fiber flax with sparsely shrubby grasses in order to create a grass cover of the rettery in conditions of radioactive contamination.

To achieve this aim, the following tasks were solved: to determine quantitative indicators characterizing the accumulation of ${ }^{137} \mathrm{Cs}$ in stems, seeds and flaxseed oil while is processing; to determine the influence of artificially created retteries and rotation of strips on the yield and quality of flax products.

Researches on hemp were aimed at studying the effect of doses and ratios of fertilizers, biostimulants on productivity, quality of 
hemp production and accumulation of ${ }^{137} \mathrm{Cs}$ by plants when grown on radioactively contaminated peat-bog soils of Polissya. The experiments are based on quite common in the Polissya area lowland peat-bog soils rich in organic matter. The depth of peat varies between 1.0-1.5 m, concerning the depth of peat horizons they are medium-deep. According to the granulometry and lithology of the underlying rock are on sandstones and loams, they are mesotrophic. According to the botanical composition peat is of sedge-reed origin. The high-fiber hemp variety YUSO-31 was used for the research. Sowing was carried out in optimal agronomic terms. The sowing rate was 4 million hectares of similar seeds, and the width between rows was $15 \mathrm{~cm}$ [5].

The ${ }^{137} \mathrm{Cs}$ content was determined by gamma spectrometry. Samples weighing more than $50 \mathrm{~g}$ and with a volume of more than $30 \mathrm{ml}$ were spectrometered on an AMA-03F machine with a NaI detector. The specific activity of ${ }^{137} \mathrm{Cs}$ in samples with lower weight and volume was determined at the Swedish Agricultural University (city Uppsala) on a gamma spectrometric system equipped with a Gedetector (ORTEC, PסT) and a multichannel analyzer (ORTEC Adcam).

\section{RESULTS AND THEIR DISCUSSION}

The specific activity of fiber flax seeds grown at high levels of radionuclide contamination of soils (pollution density of ${ }^{137} \mathrm{Cs}$ is $20.5 \mathrm{Ci} / \mathrm{sq} . \mathrm{km}$ ) was ${ }^{137} \mathrm{Cs}$ of $510 \mathrm{~Bq} / \mathrm{kg}$, which allows to use them for sowing purposes, as well as to process them into oil. The obtained seeds in all years of research had high sowing qualities - germination energy, laboratory and field germination. At the same time, the chaff after threshing flax had a content of ${ }^{137} \mathrm{Cs}$ of $1539 \mathrm{~Bq} / \mathrm{kg}$ (Table 1), so it is impractical to use it as food.

The stalks of linseed flax contain fiber suitable for the production of coarse fabrics (tarpaulin, burlap), twine, ropes and other products. Straw, which contains up to $85.0 \%$ of cellulose, serves as a raw material for the production of high-quality cigarette paper, cardboard [4; 6]. An important and urgent task today is the development of the technological process of preparation of flax straw from linseed flax stalks for further processing into fiber for the production of high quality consumer goods.

Building boards and furniture are made from waste (chaff), and chaff is also used as an alternative energy type of fuel, using energy in technological processes. Important by-products of flaxseed oil processing are oil meal and cake. In practice, the by-product cake - is more widely used in screw-pressing. According to the botanical classification, linseed flax and fiber flax are representatives of the Eurasian variety of prefabricated species - cultivated flax (Linum usitatissimum), having a similar chemical composition of bast (Table 2).

As it can be seen from Table 2 , the chemical composition of flax of different species is quite similar, and therefore in the selection of crops suitable for cultivation in conditions of radioactive contamination, it is advisable to recommend fiber flax and linseed flax.

Thus, studies of the Institute of Agriculture of Polissya NAAS, conducted on soils with a contamination density of ${ }^{137} \mathrm{Cs}$ of

Table 1. The content of radionuclides in the products of flax threshing during combine harvesting of flax (average for 2011-2003)

\begin{tabular}{lc}
\hline \multicolumn{1}{c}{ Processed products } & Specific activity of $134 \mathrm{Cs}, \mathrm{Bq} / \mathrm{kg}$ \\
\hline \hline Flax before drying & $643.6 \pm 46.5$ \\
Dried flax & $1154.4 \pm 102.3$ \\
Tangle & $743.7 \pm 62.8$ \\
Chaff & $1539.0 \pm 122.7$ \\
Seeds & $510.5 \pm 49.6$ \\
\hline
\end{tabular}


Table 2. Chemical composition of flax bast

\begin{tabular}{l|c|c|c}
\hline \multirow{2}{*}{\multicolumn{1}{c}{ Species and variety of flax }} & \multicolumn{3}{c}{ Content, \% } \\
\cline { 2 - 4 } & cellulose & lignin & pectin substances \\
\hline \hline Charming (fiber flax) & 64.99 & 4.59 & 6.90 \\
Southern Night (linseed flax) & 54.58 & 1.89 & 8.85 \\
Iceberg (linseed flax) & 67.33 & 2.09 & 12.18 \\
Debut (linseed flax) & 63.79 & 1.90 & 8.47 \\
\hline
\end{tabular}

$20.5 \mathrm{Ci} / \mathrm{sq} . \mathrm{km}$ found that the content of this radionuclide in straw and fiber flax seeds was in the range of $100-510 \mathrm{~Bq} / \mathrm{kg}$, which does not exceed the allowable levels for agricultural products $[6 ; 7]$.

High levels of radioactive contamination did not affect the growth and development of flax plants, their disease and pest damage, and the optimal fertilizer applied taking into account soil fertility, helped to obtain standing, suitable for machine harvesting and low in radionuclides products at the level of $5 \mathrm{t} / \mathrm{ha}$ (Table 3).

According to research results, using phosphoric fertilizers in the system of countermeasures in the cultivation of flax, and in their absence - granular phosphorites, it is possible to obtain flax raw material with a minimum content of ${ }^{137} \mathrm{Cs}$ (Table 3 ).

Flax is one of the few crops that has a low conversion rate of the radionuclide ${ }^{137} \mathrm{Cs}$ and is contaminated with radionuclides by secondary input [9].
About $95 \%$ of ${ }^{137} \mathrm{Cs}$ is accumulated in flax during maceration by adhesion and transfer of eolian material to plants, and the specific activity of fiber and wood from different areas of contamination does not differ significantly in increasing specific activity only in waste processing of flax straw (Table 4).

The table shows that the specific activity of ${ }^{137} \mathrm{Cs}$ in flax straw was insignificant, even in conditions of soil contamination density in the range of $186-195 \mathrm{kBq} / \mathrm{sq}$. m. However, the specific activity of ${ }^{137} \mathrm{Cs}$ in waste (dusty impurities) was much higher compared to other flax products and approached the specific activity of radiocaesium in the soil.

The use of compatible sowing of fiber flax and sparsely shrubby grasses and subsequent rotation of the strip allowed to reduce the content of radioactive cesium in flax products and thus ensure its use.

In addition, the flax straw with a high level of radioactive contamination can be washed on a squeezing-washing machine,

Table 3. The effect of fertilizers on the contamination of flax straw with radionuclides, average for 2011-2011

\begin{tabular}{l|c|c|c}
\hline \multirow{2}{*}{\multicolumn{1}{c|}{ Variant }} & \multicolumn{2}{c|}{ Specific activity of ${ }^{137} \mathrm{Cs}, \mathrm{Bq} / \mathrm{kg}$} & \multirow{2}{*}{ Transition rate } \\
\cline { 2 - 3 } & In soil & In flax straw & \\
\hline \hline Control & 528 & 14 & 0.09 \\
$\mathrm{~N}_{30} \mathrm{~K}_{90}$ & 514 & 23 & 0.15 \\
$\mathrm{~N}_{30} \mathrm{P}_{60} \mathrm{~K}_{90}$ (superphosphate) & 405 & 24 & 0.20 \\
$\mathrm{~N}_{30} \mathrm{P}_{60} \mathrm{~K}_{90}$ (phosphorite flour) & 526 & 14 & 0.09 \\
$\mathrm{~N}_{30} \mathrm{P}_{60} \mathrm{~K}_{90}$ (granular phosphorites) & 526 & 20 & 0.13 \\
$\mathrm{HIP}_{05}$ & 60,0 & 2,28 & 0.016 \\
\hline
\end{tabular}


Table 4. Specific activity of flax products with ${ }^{137} \mathrm{Cs}, \mathrm{Bq} / \mathbf{k g}$, average for $2005-2007$

\begin{tabular}{|c|c|c|c|c|c|c|c|c|}
\hline \multirow{3}{*}{$\begin{array}{l}\text { Variant of flax straw } \\
\text { aging }\end{array}$} & \multicolumn{8}{|c|}{ Density of soil pollution } \\
\hline & \multicolumn{4}{|c|}{$36-38 \mathrm{kBq} / \mathrm{sq} . \mathrm{m}$} & \multicolumn{4}{|c|}{$186-195 \mathrm{kBq} / \mathrm{sq} . \mathrm{m}$} \\
\hline & Flax straw & Fiber & Chaff & $\begin{array}{c}\text { Dusty } \\
\text { impurities }\end{array}$ & Flax straw & Fiber & Chaff & $\begin{array}{c}\text { Dusty } \\
\text { impurities }\end{array}$ \\
\hline $\begin{array}{l}\text { Without grass and } \\
\text { straw rotation } \\
\text { (control) }\end{array}$ & $>6$ & $>3$ & $>5$ & $48 \pm 11$ & $25 \pm 6$ & $>8$ & $27 \pm 6$ & $132 \pm 33$ \\
\hline $\begin{array}{l}\text { Without grass and } \\
\text { with straw rotation }\end{array}$ & & & & $51 \pm 15$ & $19 \pm 5$ & & $24 \pm 7$ & $128 \pm 28$ \\
\hline $\begin{array}{l}\text { On perennial } \\
\text { ryegrass without } \\
\text { straw rotation }\end{array}$ & & & & $52 \pm 15$ & $21 \pm 7$ & $>8$ & $23 \pm 7$ & $134 \pm 32$ \\
\hline $\begin{array}{l}\text { On perennial ryeg- } \\
\text { rass with straw }\end{array}$ & & & & $48 \pm 14$ & $17 \pm 6$ & & $21 \pm 7$ & $135 \pm 35$ \\
\hline rotation & $>6$ & $>3$ & $>5$ & & & & & \\
\hline $\begin{array}{l}\text { On meadow fescue } \\
\text { without straw } \\
\text { rotation }\end{array}$ & & & & $47 \pm 15$ & $18 \pm 5$ & & $24 \pm 5$ & $133 \pm 41$ \\
\hline $\begin{array}{l}\text { On meadow fescue } \\
\text { with straw rotation }\end{array}$ & & & & $55 \pm 19$ & $15 \pm 6$ & & $23 \pm 4$ & $134 \pm 29$ \\
\hline
\end{tabular}

followed by drying in a stream of air. In addition, this operation allows to reduce the content of radionuclides in it by 1.5-2.0 times and the dustiness of the working area during the processing of the flax straw on the scutching-and-breaking machine to the level allowed by sanitary norms (Table 5 ).

As shown by the analysis (Table 5), the content of radionuclides in long and short flax fiber from flax straw obtained by aging flax straw with a high level of radioactive contamination is in the range of $390-430 \mathrm{~Bq} / \mathrm{kg}$, which does not exceed the permissible norms for agricultural products. Washing of flax straw allows to reduce pollution of it and flax fiber by 1.5 times.

This technology allows the use of flax straw from the area of radioactive contamination and recycle it without harm to the health of workers. The cost of washing flax straw is fully offset by increasing the yield and improving the quality of the fiber with this technology. In this case, water for washing flax straw can be used repeatedly [7; 8].

Table 5. The effect of washing flax straw on its contamination and flax fiber with radionuclides ${ }^{137} \mathrm{Cs}$, average for 2003-2007

\begin{tabular}{c|l|c}
\hline № & \multicolumn{1}{c}{ Variant } & Specific activity, Bq/kg \\
\hline \hline 1 & Flax straw without washing (control) & $850 \pm 93.5$ \\
2 & Washed flax straw & $600 \pm 79.1$ \\
3 & Flax fiber scutched from flax straw without washing & $390 \pm 22.8$ \\
4 & Flax fiber scutched from washed flax straw & $270 \pm 26.5$ \\
5 & Short flax fiber from flax straw without washing & $430 \pm 66.3$ \\
6 & Short flax fiber from washed flax straw & $350 \pm 54.5$ \\
\hline
\end{tabular}


It is known that the higher the agronomic background is created by applying fertilizers, the higher the productivity of hemp plants.

Thus, the application of mineral fertilizers in the norm of $\mathrm{N}_{60} \mathrm{P}_{60} \mathrm{~K}_{120}$ provided an increase in fiber by $8.5 \mathrm{c} /$ ha compared to the control (without fertilizers), in the control $11.2 \mathrm{c} /$ ha of fiber was obtained. The highest fiber yield from straw (32\%) was obtained when applying mineral fertilizers at the rate of P60K60 in combination with the biostimulator EM-4, with the best fiber strength (32.6 daN).

On peat-bog soils, in conditions of potassium deficiency, in the processes of plant metabolism the plants use its chemical analogue cesium. This is confirmed by the fact that the application of mineral fertilizers, which include potassium, dramatically reduces the uptake of cesium by plants.

The mobility of cesium in these soils can be explained by the insignificant content of the mineral part in them, due to which its fixation takes place. Soil minerals are known to be a source from which potassium reserves are replenished. From this point of view, the low mineral content also promotes the transition of cesium into plants. The use of mineral fertilizers in combination with biostimulants helped to reduce the inflow of radiocaesium from the soil into the production of hemp: fiber and chaff. Thus, when growing hemp on contaminated peat-bog soils without fertilizers (control), radiocaesium was accumulated in the fiber in the amount of $237 \mathrm{~Bq} / \mathrm{kg}$ and in the chaff in the amount of $319 \mathrm{~Bq} / \mathrm{kg}$, while mineral fertilizers in the norm $\mathrm{P}_{60} \mathrm{~K}_{150}$ in combination with the biostimulator EM-4 reduced the accumulation in the fiber up to $118 \mathrm{~Bq} / \mathrm{kg}$, and in the chaff up to $96 \mathrm{~Bq} / \mathrm{kg}$, or $119 \mathrm{~Bq} / \mathrm{kg}$ and $223 \mathrm{~Bq} / \mathrm{kg}$, respectively, compared with the control. These data indicate a high $\mathrm{KN}$ of radiocaesium in the «soil-plant» chain, especially in terms of the structure of accumulation, chaff accumulates more radiocaesium than hemp fiber $[1 ; 5]$.

Analyzing the data, we can conclude that phosphorus-potassium fertilizers and biostimulants have a positive effect on hemp productivity. The content of radionuclides in the fiber and chaff is reduced by $2.0-2.5$ times by the introduction of phosphorus-potassium fertilizers and the use of biostimulants.

\section{CONCLUSION}

Fiber flax, linseed flax and hemp are crops that are recommended for cultivation in conditions of radioactive contamination due to a complex of economic and biological characteristics. On soils with a high level of such contamination, these crops accumulate a minimum amount of radionuclides. These crops and areas of their cultivation and processing deserve priority in the use of land contaminated with radionuclides.

In the system of countermeasures in the cultivation of flax and hemp in the fertilizer system it is necessary to use phosphorus-potassium fertilizers, which will significantly reduce the flow of radionuclides into products.

Combined sowing of fiber flax and sparsely shrubby grasses and subsequent rotation of the strip allows to reduce the content of ${ }^{137} \mathrm{Cs}$ in flax straw, which is grown at different levels of density of radioactive contamination of the soil.

Prior to processing on the scutchingand-breaking machine of the straw with the increased content of radionuclides it is necessary to wash it in a stream on the squeezing-washing machine.

Further research will improve the technology of growing bast crops on radiationcontaminated soils and the technology of processing raw materials, which will reduce the specific activity to acceptable levels.

\section{ЛIТЕРАТУРА}

1. Савченко Ю.І., Ковальов В.Б., Мельничук А.О. Вплив контрзаходів на вміст радіоцезію у грунті та сільськогосподарській продукції через 17 років після аварії на ЧАЕС. Проблеми сільськогосподарської радіологї: 17 років після аварї̈ на ЧАЕС: тези доповідей на 4-й міжнар. наук.-практ. конф. (м. Житомир, 19-21 черв. 2003 р.). Житомир, 2003. С. 3-13.

2. Посівні площі сільськогосподарських культур під урожай 2017 року: Статистичний бюлетень. Київ: Вид-во державної служби статистики. 2017. $49 \mathrm{c}$. 
3. Ковальов В.Б., Ткачук В.П, Бучко К.Д. Особливості формування врожаю льону олійного на Поліссі. Агропромислове виробництво Полісся. 2016. Вип. 9. С. 7-15.

4. Рой О.О. Аналіз фізико-механічних показників льону олійного. Проблеми легкої $і$ текстильної промисловості України. 2008. № 1 (13). С. 7475.

5. Гудзь Г.А., Ковальов В.Б., Фещенко В.Г, Гудзь І.Л. Біоконверсія конопель на радіоактивно забруднених торфово-болотних грунтах Полісся. Проблеми сільськогосподарської радіологї: 17 років після аварї на ЧАEC: тези доповідей на 4-й міжнар. наук.-практ. конф. (м. Житомир, 19-21 черв. 2003 р.). Житомир, 2003. С. 146-148.
6. Ковалев В.Б. Производство продукции в условиях радиоактивного загрязнения. Проблемь с.-х. радиоэкологии: 10 лет после аварии на Чернобыльской $A E C$ : тез. докл. 2-й междунар. конф. (г. Житомир, 1996 г.). Житомир, 1996. С. 26-29.

7. Ковальов В.Б., Бовсунівський М.В. Виробництво льону на радіоактивно забруднених грунтах: метод. посіб. Київ: Мінсільгосппрод, 1992. C. 67-68.

8. Ковальов В.Б. Екологічно чиста продукція льону в умовах радіаційного забруднення. Натураліум. 1996. № 3. C. 52-56.

9. Дідора В.Г., Деребон. Шляхи відродження льонарства в Україні. Вісник ДАУ. 2004. № 1. C. $40-45$.

\section{REFERENCES}

1. Savchenko, Yu.I., Kovalev, V.B. \& Mel'nychuk, A.O. (2003). Vplyv kontrzakhodiv na vmist radiotseziyu u hruntita sil's'kohospodars'kiy produktsiyi cherez 17 rokiv pislya avariyi na CHAES [The impact of countermeasures on the content of radiocaesium in soil and agricultural products 17 years after the Chernobyl accident]. Problemy sil's'kohospodars'koy iradiolohiyi: 17 rokiv pislya avariyi na CHAES: Tezy dopovidey na 4-y mizhnarodniy naukovo-praktychniy konferentsiyi [Problems of agricultural radiology: 17 years after the Chernobyl accident: abstracts of reports at the 4th International Scientific and Practical Conference] (pp. 3-13). Zhytomyr [in Ukrainian].

2. Posivni ploshchi sil's'kohospodars'kykh kul'tur pid urozhay 2017 roku: Statystychnyy byuleten' [Sown areas of crops for the 2017 harvest: Statistical Bulletin]. Kyiv [in Ukrainian].

3. Kovalev, V.B., Tkachuk, V.P. \& Buchko, K.D. (2016). Osoblyvosti formuvannya vrozhay ul'onuo liynoho na Polissi [Features of the production of flaxseed oil on Polissya]. Ahropromyslove vyrobnytstvo Polissya - Agroindustrial production of Polissya, 9, 7-15 [in Ukrainian].

4. Roy, O.O. (2008). Analiz fizyko-mekhanichnykh pokaznykiv l'onuoliynoho [Analysis of physico-mechanical parameters of flaxen oil]. Problemy lehkoyi I tekstyl'noyi promyslovosti Ukrayiny - Problems of the light and textile industry of Ukraine, 1 (13), 74-75 [in Ukrainian].

5. Gudz', G.A., Kovalev, V.B., Feschenko, V.G. \& Gudz, 'I.L. (2003). Biokonversiya konopel' na radioaktyvno zabrudnenykh torfovo-bolotnykh hruntakh Polissya [Bioconversion of hemp on radioactively contaminated peat-swamp soils of Polissya]. Problemy sil's' kohospodars' koyi radiolohiyi: 17 rokiv pislya avariyina CHAES: Tezy dopovidey na 4-y mizhnarodniy naukovo-praktychniy konferentsiyi [Problems of agricultural radiology: 17 years after the Chernobyl accident: abstracts of reports on the 4th International Scientific and Practical Conference] (pp. 146-148). Zhytomyr [in Ukrainian].

6. Kovalev, V.B. (1996). Proyzvodstvo produktsyy v uslovyiakh radyoaktyvnoho zahriaznenyia [Production of products in the conditions of radioactive contamination]. Problemy sil's'kohospodars' koyi radyo'kolohyy: 10 let posle avaryy na Chernobyl'skoy AES: tezy dokladiv 2-y mezhdunarodnoyi konferentsiyi [Problems of agricultural radioecology: 10 years after the Chernobyl accident: abstracts of the 2nd International Conference] (pp. 67-68). Zhytomyr [in Russian].

7. Kovalev, V.B. \& Bovsunivs'kuy, M.V. (1992). Vyrobnytstvo l'onu na radioaktyvno zabrudnenykh gruntakh: metod. posib. [Flax production on radioactive contaminated soils: a method. way]. Kyiv [in Ukrainian].

8. Kovalev, V.B. (1996). Ekolohichno chysta produktsiya l'onu v umovakh radiatsiynoho zabrudnennya [Ecologically pure flax production in conditions of radiation pollution]. Naturalium - Naturalium, 3, 52-56 [in Ukrainian].

9. Didora, V.G. \& Derebon, I.Yu. (2004). Shlyakhy vidrodzhennya l'onarstva $\mathrm{v}$ Ukrayini [Ways of revival of flax in Ukraine]. Visnyk DAU - Bulletin DAEU, 1, 40-45 [in Ukrainian].

Стаття надійшла до редакції журналу 23.04.2020 